\title{
Ingestive behavior and temperament of Nellore cattle classified for residual feed intake
}

\section{Comportamento ingestivo e temperamento de bovinos Nelore classificados por consumo alimentar residual}

\author{
Julian Aldrighi ${ }^{1}$; Renata Helena Branco ${ }^{1}$; Joslaine Noely dos Santos Gonçalves \\ Cyrillo $^{1}$; Elaine Magnani ${ }^{1}$; Cleisy Ferreira do Nascimento ${ }^{1}$; Sarah Figueiredo \\ Martins Bonilha $^{1}$; Maria Eugênia Zerlotti Mercadante ${ }^{1^{*}}$
}

\begin{abstract}
The objective of this study was to evaluate the relationship between ingestive behavior, temperament and residual feed intake (RFI) in Nellore cattle. Sixty-two bulls and 56 heifers after weaning, housed in individual pens, were evaluated in individual performance tests. Animals were classified as low RFI $\left(<-0.128 \mathrm{~kg} \mathrm{day}^{-1}\right.$; less than mean minus 0.5 standard deviation), medium RFI (-0.128 to $0.135 \mathrm{~kg}$ day $^{-1} ; \pm 0.5$ standard deviation), and high RFI ( $>0.135 \mathrm{~kg} \mathrm{day}^{-1}$; greater than mean plus 0.5 standard deviation). Ingestive behavior was evaluated for $24 \mathrm{~h}$ by direct observation, every 24 days in bulls or every 10 days in heifers. Temperament was assessed by flight speed, reactivity in mobile confinement, composite score, and serum cortisol measurement. The most efficient animals (low RFI, $5.6 \mathrm{~kg} \mathrm{DM}$ day $^{-1}$ ) consumed $7 \%$ less feed than animals with medium efficiency (mean RFI, $6.0 \mathrm{~kg} \mathrm{DM}$ day $^{-1}$ ) and $13 \%$ less than the least efficient animals (high RFI, $6.34 \mathrm{~kg} \mathrm{DM} \mathrm{day}^{-1}$ ). More feed efficient animals spent a longer time feeding and ruminating per kg of DM consumed. Similarly, more efficient animals consumed less DM per hour and ruminated less DM per hour, but made the same number of visits to the feed bunk. High-efficiency animals were $13 \%$ and $35 \%$ faster to walk $1.77 \mathrm{~m}$ after release from the scale than medium- and low-efficiency animals, respectively, suggesting a more reactive temperament without differences in reactivity, composite score, or serum cortisol. Feed efficiency is associated with ingestive behavior and temperament in Nellore cattle. More efficient animals consume and ruminate less feed over the same period of time than animals with medium and low feed efficiency. In addition, more efficient animals exhibit a faster flight speed and are more reactive than less efficient animals.
\end{abstract}

Key words: Beef cattle. Behavior. Feed efficiency. Feed intake.

\section{Resumo}

O objetivo deste trabalho foi avaliar a relação entre comportamento ingestivo, temperamento e consumo alimentar residual (CAR) em bovinos Nelore. Foram avaliados em teste de desempenho individual 62 machos (idade e peso inicial, 261 dias e $261 \pm 26,8 \mathrm{~kg}$ ) e 56 fêmeas (idade e peso inicial, 293 dias e $207 \pm 19,2 \mathrm{~kg}$ ), alojados em baias individuais. Os animais foram classificados como baixo CAR (< $-0,128 \mathrm{~kg}$ /dia; 0,5 desvio padrão abaixo da média; 19 fềmeas e 21 machos), médio CAR (-0,128 a 0,135 $\mathrm{kg} / \mathrm{dia} ; \pm 0,5$ desvio padrão; 21 fêmeas e 21 machos), e alto CAR (>0,135 kg/dia; 0,5 desvio padrão acima da média; 16 fêmeas e 20 machos). O comportamento ingestivo foi avaliado a cada 24 dias

\footnotetext{
' Instituto de Zootecnia, Centro Avançado de Pesquisa de Bovinos de Corte, Sertãozinho, SP, Brasil. E-mail: julian aldrighi@ hotmail.com; renata@iz.sp.gov.br; cyrillo@iz.sp.gov.br; lainemag@hotmail.com; cleisycfn@yahoo.com.br; sbonilha@iz.sp. gov.br; mercadante@iz.sp.gov.br
}

Author for correspondence 
(machos) ou a cada 10 dias (fêmeas), durante $24 \mathrm{~h}$, por meio de observações diretas. O temperamento foi avaliado pela velocidade de saída, reatividade em ambiente de contenção móvel, escore composto, e dosagem de cortisol sérico. Animais mais eficientes consumiram (baixo CAR; 5,60 kg MS/dia), em média, 7\% menos alimento que os animais de média eficiência (médio CAR; 6,00 kg MS/dia) e 13\% menos alimento que os animais menos eficientes (alto CAR; 6,34 kg MS/dia). Animais mais eficientes apresentaram maior tempo de alimentação por kg de matéria seca ingerida $(\mathrm{P}=0,03)$, assim como maior tempo de ruminação por $\mathrm{kg}$ de matéria seca ingerida $(\mathrm{P}<0,01)$. Da mesma forma, animais mais eficientes consumiram menor quantidade de matéria seca por hora $(\mathrm{P}=0,03)$ e ruminaram menor quantidade de matéria seca por hora $(\mathrm{P}<0,01)$, mas com mesma frequência de visitas ao cocho $(\mathrm{P}=0,18)$. Animais classificados como mais eficientes foram, em média, $13 \%$ e $35 \%$ mais rápidos $(\mathrm{P}=0,02)$ para percorrer $1,77 \mathrm{~m}$ logo após sair da balança, do que os animais de média e baixa eficiência alimentar, sugerindo temperamento mais reativo, sem diferenças nas variáveis reatividade em ambiente de contenção móvel, escore composto, e dosagem de cortisol sérico. A eficiência alimentar tem relação com comportamento ingestivo e com o temperamento em bovinos da raça Nelore. Animais mais eficientes ingerem e ruminam menor quantidade de alimento em um mesmo período de tempo que os animais de média e de baixa eficiência alimentar. Animais mais eficientes apresentam maior velocidade de saída e podem ser considerados mais reativos que animais menos eficientes.

Palavras-chave: Bovinos de corte. Comportamento. Eficiência alimentar. Consumo de alimentos.

\section{Introduction}

An efficient strategy to render beef cattle production systems more profitable is to reduce feed costs and to adopt practices that will enable better dietary nutrient utilization by cattle. Feed is the most expressive cost component, exceeding $70 \%$ of total production costs when the purchase value of the animal is disregarded (PACHECO et al., 2006).

Residual feed intake (RFI) is a measure of feed efficiency that permits to identify animals with similar performance but that differ in terms of energy requirements for maintenance and production. Evidence from beef cattle indicates that more efficient animals spent less time at the feed bunk than less efficient animals (GOMES et al., 2013; GUIMARÃES et al., 2017; KELLY et al., 2010), possibly saving energy in this activity and spending more time in sedentary activities. Furthermore, a higher feed efficiency of animals might be associated with less stress and lower circulating cortisol concentrations (GOMES et al., 2013; LLONCH et al., 2016). However, negative ou null phenotypic correlations (LLONCH et al., 2016; ROLFE et al., 2011) was observed between RFI and flight speed (as a measure of temperament).

Studies on this topic involving indicine cattle breeds (Bos indicus) are sparse. In this respect, investigation of the associations between RFI and behavioral variables in Nellore cattle will lead to a better understanding of the causes of variation in feed efficiency between animals and to a less expensive and faster identification of more efficient animals. The objective of the present study was to evaluate the ingestive behavior and temperament of Nellore cattle classified for RFI.

\section{Material and Methods}

The study was conducted in Sertãozinho, SP, Brazil ( $21^{\circ} 10^{\prime} \mathrm{S}$ and $\left.48^{\circ} 5^{\prime} \mathrm{W}\right)$. Research on animals was conducted according to the institutional committee on animal use (São Paulo State Law No. 11.977).

Sixty-two bulls (initial age and weight, 261 days and $261 \pm 26.8 \mathrm{~kg}$ ) and 56 heifers (initial age and weight, 293 days and $207 \pm 19.2 \mathrm{~kg}$ ), housed in individual pens, were evaluated in performance tests. There was one facility for bulls and two facilities for heifers. The male performance test had a duration of 72 days after an adaptation period of 35 days, and the female performance test had a duration of 84 days after 28 days of adaptation. During the tests, bulls were weighed twice a week without previous fasting ( 22 weight recordings) and 
heifers were weighed every 28 days after a 16-h fast from water and feed (4 weight recordings). The two weighing procedures (BIF, 2010) were done to attend a second experiment (NASCIMENTO et al., 2015). The diet (Table 1) was offered daily at two times, $08 \mathrm{~h} 00$ and $15 \mathrm{~h} 00$. The leftovers of each animal were weighed, recorded and adjusted to maintain them between $5 \%$ and $10 \%$ of the feed offered.

Table 1. Composition and nutritional characteristics of the diet.

\begin{tabular}{lc}
\hline Item & Diet composition, $\mathrm{g} / \mathrm{kg} \mathrm{DM}$ \\
\hline Urochloa spp. hay & 445 \\
Ground corn & 322 \\
Cottonseed meal & 214 \\
Urea & 4.5 \\
Ammonium sulfate & 0.5 \\
Mineral salt ${ }^{1}$ & 14 \\
F:C ratio & $45: 55$ \\
Chemical composition & \\
$\quad$ Dry matter (\%) & 93.4 \\
$\quad$ Organic matter (\% DM) & 96.3 \\
$\quad$ Crude protein (\% DM) & 11.3 \\
$\quad$ NDF (\% DM) & 50.0 \\
$\quad$ ADF (\% DM) & 31.0 \\
Cellulose (\% DM) & 23.9 \\
$\quad$ Lignin (\% DM) & 6.18 \\
$\quad$ Ether extract (\% DM) & 2.84 \\
ME Mcal kg ${ }^{-1}$ & 2.00 \\
\hline
\end{tabular}

${ }^{1}$ Composition per kilogram: $8 \%$ phosphorus, $15 \%$ calcium, $14.5 \%$ sodium, $1.2 \%$ sulfur, $1.1 \%$ nickel, $0.25 \%$ zinc, $0.16 \%$ copper, $0.16 \%$ manganese, $0.0011 \%$ cobalt, $0.0023 \%$ iodine, $0.0027 \%$ selenium, and $0.08 \%$ fluoride.

$\mathrm{F}: \mathrm{C}$ ratio: proportion between the amounts of forage and concentrate in the diet. NDF: neutral detergent fiber; ADF: acid detergent fiber; ME: metabolizable energy.

The daily dry matter intake (DMI) of each animal was calculated as the difference between feed offered and orts multiplied by dry matter (DM) content, and is reported as the average DMI of the test period. To obtain the DM content of the diet, two weekly samples were obtained to compose one sample every 28 days. The samples were pre-dried in a ventilated oven at $55^{\circ} \mathrm{C}$ for $72 \mathrm{~h}$, ground in a Wiley mill (sieve of $1 \mathrm{~mm}$ ), and dried in an oven at $105^{\circ} \mathrm{C}$ for $8 \mathrm{~h}$.

\section{Residual Feed Intake}

Average daily gain (ADG) of the animal was estimated by linear regression of weights on days on test, and the initial body weight (iBW) was estimated by the intercept of the regression line. The mid-test metabolic body weight $\left(\mathrm{BW}^{0.75}\right)$ was calculated as: $\mathrm{BW}^{0.75}=[\mathrm{iBW}+1 / 2(\mathrm{ADG} \times$ days on test) $]^{0.75}$ (GRION et al., 2014).

Residual feed intake was calculated as the difference between observed DMI and expected DMI (eDMI) as described by Koch et al. (1963). 
The following linear regression model was adjusted to estimate eDMI separately for bulls and heifers: $\mathrm{eDMI}=\alpha+\beta_{1} \times \mathrm{ADG}+\beta_{2} \times \mathrm{BW}^{0.75}+\varepsilon$, where $\beta_{1}$ and $\beta_{2}$ are the partial regression coefficients of $\mathrm{DMI}$ on $\mathrm{ADG}$ and $\mathrm{BW}^{0.75}$, and $\varepsilon$ is the random error (which represents RFI). For heifers, the fixed effect of facility was included in the regression model. The animals were classified as low RFI $(<-0.128 \mathrm{~kg}$ day $^{-1}$; less than mean minus 0.5 standard deviation; $\mathrm{n}=40)$, medium RFI ( -0.128 to $0.135 \mathrm{~kg} \mathrm{day}^{-1} ; \pm 0.5$ standard deviation; $\mathrm{n}=42)$, and high RFI $(>0.135 \mathrm{~kg}$ $\mathrm{day}^{-1}$; greater than mean plus 0.5 standard deviation; $n=36$ ).

\section{Ingestive behavior}

Ingestive behavior was evaluated for $24 \mathrm{~h}$, every 24 days in bulls or every 10 days in heifers. Direct observations were made by eight trained observers (3 h daily each) using focal sampling and instantaneous sampling at intervals of 5 minutes. Artificial lightning was used at night of evaluation days, with prior adaptation of the animals. The following behavioral categories were evaluated: feeding (the animal stands in front of the feed bunk, with the head down or not, chewing after prehension or chewing with the muzzle dirty of feed without apparent prehension), ruminating (the animal is chewing, swallowing, regurgitating, and re-chewing, with the bolus appearing on the side of the cheek), and idling (the animal is engaged in any activity not related to solid feeding). The chewing rate was determined during peaks of mastication, one day after the measurements described above. Three rumen boluses were observed per animal for the quantification of the number and chewing time.

The following variables, expressed as min day ${ }^{-1}$, were obtained as the total time the animal spent in each activity: feeding time (FT), rumination time (RT), and idle time (IT), considering the day to have 1,440 min. The total duration of FT and RT was also divided by the amount of feed consumed ( $\mathrm{kg}$ of DM), FT (min $\mathrm{kg} \mathrm{DM}^{-1}$ ) and RT (min kg
$\mathrm{DM}^{-1}$ ), and the inverse relationship, providing the feeding efficiency (FE, g DM hour ${ }^{-1}$ ) and rumination efficiency (RE, $g$ DM hour ${ }^{-1}$ ). The feeding frequency (FF, visits day ${ }^{-1}$ ) was determined by the number of times the animal visited the feed bunk over the period of 24 h (GOMES et al., 2013; NKRUMAH et al., 2007).

\section{Temperament}

The temperament measures were obtained at the beginning and end of the performance test. Flight speed (FS) was measured with a flight speed equipment (BURROW et al., 1988) to record the time the animals took to cover a distance of 1.77 $\mathrm{m}$ after release from the weigh scale where they were restrained individually. Faster animals are considered more reactive.

Reactivity (REAT) was assessed by the movement of the animal on the weigh scale using the REATEST ${ }^{\circledR}$ device (Bios Serviços e Comércio Ltda., Belo Horizonte, MG, Brazil), which consists of a reactivity test in mobile cage (MAFFEI et al., 2006). The device was attached beneath the scale and programmed to record the first $5 \mathrm{~s}$ of movement of the animal after the last door of the scale was closed. FS and REAT were obtained only in bulls.

The composite score (CS), adapted from Fordyce et al. (1982) and described by Piovezan et al. (2013), was recorded during the first $5 \mathrm{~s}$ of entry of the animal into the scale. The following scores were attributed by the same evaluator: 1 = calm, no movement, no audible breathing; 2 = restless, shifting the position of the legs; 3 = squirming, trembling, occasionally moving the scale, occasional audible breathing; 4 $=$ continuous and vigorous movements, moving the scale, audible breathing; $5=$ continuous and vigorous movements, moving the scale, turning or struggling violently, audible breathing.

Blood samples for the measurement of serum cortisol were obtained at the beginning and end of the performance test after a 12 -h fast from solids. 
The samples were collected by puncture of the jugular vein with $25 \times 8$ needles into 10 -ml vacutainer tubes containing heparin (Labor IMPORT, sodium heparin). The tubes were centrifuged immediately after collection for $20 \mathrm{~min}$ at 3,000 rpm for the separation of plasma. The concentration of cortisol was determined determined colorimetrically by ELISA (Accubind, Monobind, Inc., Lake Forest, CA). The intra-assay coefficients of variation were $8.2,6.4$, and $6.1 \%$ for the low, medium, and high standard, respectively, and the interassay coefficients of variation were 9.7, 7.0, and $7.3 \%$.

\section{Statistical analysis}

For analysis of the ingestive behavior variables, each performance test was divided into three equal periods and the mean per period of each variable was obtained. The ingestive behavior variables were analyzed with the MIXED procedure (SAS Institute, Inc., Cary, NC) considering the three periods as repeated measures. The model included the random effects of animal and facility $(1, \ldots$, $3)$, the fixed effects of RFI class $(1, \ldots, 3)$, sex $(1$, 2 ) and period $(1, \ldots, 3)$, the linear effect of animal age at mid-test and random error. A first-order heterogenous autoregressive matrix (1), chosen based on Schwarz's Bayesian criterion, was used to model the error variance across the periods and the correlations between them.

The temperament variables (FS, REAT and CS) and cortisol concentration were analyzed as the mean of measures obtained at the beginning and end of the test. The model included the random effects of animal and facility $(1, \ldots, 3)$, the fixed effects of RFI class $(1, \ldots, 3)$ and sex $(1,2)$, the linear effect of animal age at mid-test and random error, except for the analysis model of FS and REAT which did not include the effect of sex since these variables were only obtained in bulls. For all analyses, means were compared between sexes using Fisher's least significant difference (i.e., PDIFF option of the LSMEANS command). Differences were considered to be significant when $\mathrm{P} \leq 0.05$.

Simple correlations between the feed efficiency, ingestive behavior and temperament variables were estimated with the CORR procedure (SAS Institute, Inc., Cary, NC).

\section{Results}

The most efficient animals (low RFI; $5.6 \mathrm{~kg}$ DM day $^{-1}$ ) consumed on average $7 \%$ less feed than animals with medium efficiency (mean RFI; $6.0 \mathrm{~kg} \mathrm{DM} \mathrm{day}^{-1}$ ) and $13 \%$ less than the least efficient animals (high RFI; $6.34 \mathrm{~kg} \mathrm{DM} \mathrm{day}{ }^{-1}$ ), but exhibited similar initial and final weights, ADG and $\mathrm{BW}^{0.75}$ obtained during the test (Table 2). In terms of percentage of body weight, the most efficient animals consumed $8 \%$ less feed $(2.19 \%$ of body weight) than medium-efficiency animals $(2.36 \%$ of body weight) and $16 \%$ less than low-efficiency animals (2.54\% of body weight).

More feed efficient animals spent a longer time feeding $(\mathrm{P}=0.03)$ and ruminating $(\mathrm{P}<0.01)$ per $\mathrm{kg}$ of DM consumed. Similarly, more efficient animals consumed less DM per hour $(\mathrm{P}=0.03)$, measured by FE (g DM hour ${ }^{-1}$ ), and ruminated less DM per hour $(\mathrm{P}<0.01)$, measured by RE ( $\mathrm{g} D M$ hour $^{-1}$ ), but made the same number of visits to the feed bunk $(\mathrm{P}=0.18)$. This finding indicates that high-efficiency animals consumed and ruminated less feed over the same period of time than medium- and low-efficiency animals. No differences $(\mathrm{P}>0.05)$ in FT, RT or IT were observed between more and less efficient animals.

The correlations between DMI and the ingestive behavior variables were close to zero, except for the variables that include DMI in the definition. The correlations of these variables with DMI were high and negative or positive depending on the definition of the trait. 
Table 2. Performance, feed efficiency and ingestive behavior of growing Nellore cattle according to residual feed intake class.

\begin{tabular}{|c|c|c|c|c|c|}
\hline & & RFI class & & & \\
\hline Variable & Low $(n=40)$ & Medium $(n=42)$ & $\operatorname{High}(\mathrm{n}=36)$ & SEM & $P$ \\
\hline RFI (kg DM day $\left.{ }^{-1}\right)$ & $-0.32 \mathrm{a}$ & $0.017 \mathrm{~b}$ & $0.34 \mathrm{c}$ & 0.02 & $<0.01$ \\
\hline iBW (kg) & 237 & 235 & 231 & 16.8 & 0.54 \\
\hline fBW (kg) & 299.1 & 292.4 & 292.48 & 16.6 & 0.43 \\
\hline $\mathrm{BW}^{0.75}(\mathrm{~kg})$ & 66.3 & 65.5 & 64.9 & 3.16 & 0.47 \\
\hline DMI (kg/day) & $5.60 \mathrm{a}$ & $6.00 \mathrm{~b}$ & $6.34 \mathrm{c}$ & 0.12 & $<0.01$ \\
\hline DMI [( $\left.\left.\mathrm{kg} \mathrm{DM} \mathrm{kg} \mathrm{BW}^{-1}\right) \times 100\right]$ & $2.19 \mathrm{a}$ & $2.36 \mathrm{~b}$ & $2.54 \mathrm{c}$ & 0.19 & $<0.01$ \\
\hline $\operatorname{ADG}\left(\mathrm{kg} \mathrm{day}^{-1}\right)$ & 0.77 & 0.77 & 0.77 & 0.02 & 0.98 \\
\hline FT $\left(\right.$ min day $\left.{ }^{-1}\right)$ & 238 & 240 & 240 & 3.02 & 0.84 \\
\hline $\mathrm{FT}\left(\min \mathrm{kg} \mathrm{DM}^{-1}\right)$ & $68 \mathrm{a}$ & $66 a b$ & $64 \mathrm{~b}$ & 1.03 & 0.03 \\
\hline FE (g DM hour $\left.{ }^{-1}\right)$ & $1227 \mathrm{a}$ & $1295 b$ & $1336 b$ & 29.6 & 0.03 \\
\hline $\mathrm{RT}\left(\min\right.$ day $\left.^{-1}\right)$ & 455 & 449 & 463 & 6.97 & 0.31 \\
\hline $\mathrm{RT}\left(\min \mathrm{kg} \mathrm{DM}^{-1}\right)$ & $80 \mathrm{a}$ & $75 b$ & $74 \mathrm{~b}$ & 1.63 & $<0.01$ \\
\hline RE (g DM hour ${ }^{-1}$ ) & $759 a$ & $818 b$ & $838 \mathrm{~b}$ & 16.2 & $<0.01$ \\
\hline IT (min day $\left.{ }^{-1}\right)$ & 746 & 746 & 735 & 7.76 & 0.53 \\
\hline FF (visits day ${ }^{-1}$ ) & 15.4 & 16.2 & 15.7 & 0.33 & 0.18 \\
\hline
\end{tabular}

RFI: residual feed intake; iBW: initial body weight; fBW: final body weight; $\mathrm{BW}^{0.75}$ : mid-test metabolic body weight; ADG: average daily gain; DMI: dry matter intake; FT: feeding time; FE: feeding efficiency; RT: rumination time; RE: rumination efficiency; IT: idle time; FF: feeding frequency; SEM: standard error of the mean. Means in the same row followed by different superscript letters differ significantly from one another $(\mathrm{P}<0.05)$.

In general, the correlations between $\mathrm{ADG}$ and the ingestive behavior variables were significant and of medium magnitude (Table 3 ). The variables indicating a longer time spent feeding (RT in min day $^{-1}$ and FF in min day ${ }^{-1}$, except for FT in min day $\left.{ }^{1}\right)$ and those indicating faster feeding (FE and RE) were positively correlated with ADG. The variable that indicates less time spent feeding (IT), as well as the variables that indicate slower feeding (longer time spent per $\mathrm{kg}$ of feed consumed, i.e., FT in min $\mathrm{kg}^{-1} \mathrm{DM}$ and RT in min $\mathrm{kg} \mathrm{DM}^{-1}$ ), were negatively correlated with ADG.

Table 3. Simple correlation of performance and feed efficiency with ingestive behavior.

\begin{tabular}{lccc}
\hline & DMI & ADG & RFI \\
\hline FT $\left(\right.$ min day $\left.^{-1}\right)$ & -0.006 & -0.009 & 0.12 \\
FT $\left(\right.$ min kg DM $\left.^{-1}\right)$ & $-0.78^{*}$ & $-0.42^{*}$ & -0.05 \\
FE $\left(\mathrm{g} \mathrm{DM} \mathrm{hour}^{-1}\right)$ & $0.74^{*}$ & $0.39^{*}$ & 0.07 \\
RT $\left(\right.$ min day $\left.^{-1}\right)$ & 0.09 & $0.27^{*}$ & $0.21^{*}$ \\
RT $\left(\right.$ min kg DM $\left.^{-1}\right)$ & $-0.77^{*}$ & $-0.27^{*}$ & -0.008 \\
RE $\left(\mathrm{g} \mathrm{DM} \mathrm{hour}^{-1}\right)$ & $0.76^{*}$ & $0.25^{*}$ & 0.02 \\
IT $\left(\right.$ min day $\left.^{-1}\right)$ & -0.07 & $-0.23^{*}$ & $-0.25^{*}$ \\
FF $\left(\right.$ visits day $\left.^{-1}\right)$ & 0.009 & $0.22^{*}$ & 0.09 \\
\hline
\end{tabular}

DMI: dry matter intake; ADG: average daily gain; RFI: residual feed intake; FT: feeding time; FE: feeding efficiency; RT: rumination time; RE: rumination efficiency; IT: idle time; FF: feeding frequency. ${ }^{*} \mathrm{P}<0.05$. 
The correlations involving RFI were close to zero, except for RT (min day $\left.{ }^{-1}\right)$ and IT $\left(\min\right.$ day $\left.^{-1}\right)$. More efficient animals tend to exhibit shorter RT and greater IT.

\section{Temperament}

Bulls classified as the most feed efficient were on average $13 \%$ and $35 \%$ faster $(\mathrm{P}=0.02)$ to cover the $1.77 \mathrm{~m}$ after release from the scale than medium- and low-efficiency animals, suggesting a more reactive temperament (Table 4). However, no significant differences were observed between more and less efficient animals in REAT obtained with the REATEST ${ }^{\circledR}$ device or CS, both measuring movement on the scale $5 \mathrm{~s}$ after restraint of the animal. Blood cortisol concentrations were also similar in animals of the three feed efficiency classes.

Table 4. Temperament and blood cortisol concentration of growing Nellore cattle according to residual feed intake class.

\begin{tabular}{lcccccc}
\hline & \multicolumn{7}{c}{ RFI class } \\
\hline Variable & $\mathrm{n}$ & Low & Medium & High & SEM & $P$ \\
\hline FS $\left(\mathrm{m} \mathrm{s}^{-1}\right)$ & 62 & $2.17^{\mathrm{a}}$ & $1.92^{\mathrm{ab}}$ & $1.61^{\mathrm{b}}$ & 0.13 & 0.02 \\
REAT & 62 & 11518 & 10706 & 11320 & 524 & 0.52 \\
CS & 118 & 2.22 & 2.26 & 2.29 & 0.17 & 0.90 \\
Cortisol $\left(\mu \mathrm{g} \mathrm{ml}^{-1}\right)$ & 118 & 5.43 & 6.03 & 5.45 & 0.34 & 0.38 \\
\hline
\end{tabular}

RFI: residual feed intake; FS: flight speed; REAT: reactivity; CS: composite score; SEM: standard error of the mean. Means in the same row followed by different superscript letters differ significantly from one another $(\mathrm{P}<0.05)$.

The correlations of DMI or ADG with the temperament measures were not significant (Table 5), except for the correlation between ADG and cortisol which was significant, positive and of low magnitude. On the other hand, a low and negative correlation was observed between FS and RFI, suggesting that more feed efficient animals tend to be more reactive.

Table 5. Simple correlation of performance and feed efficiency with temperament.

\begin{tabular}{lccc}
\hline & DMI & ADG & RFI \\
\hline FS & -0.19 & -0.19 & $-0.24^{*}$ \\
REAT & 0.05 & 0.18 & -0.01 \\
CS & -0.01 & -0.15 & 0.02 \\
Cortisol $\left(\mu \mathrm{g} \mathrm{ml}^{-1}\right)$ & 0.06 & $0.21^{*}$ & 0.07 \\
\hline
\end{tabular}

DMI: dry matter intake; ADG: average daily gain; RFI: residual feed intake; FS: flight speed; REAT: reactivity; CS: composite score. $* \mathrm{P} \leq 0.05$.

The correlations between temperament measures were close to zero, except for the correlation between FS and CS which was positive and of medium magnitude (Table 6), indicating consistency between these two temperament measures. 
Table 6. Simple correlation between temperament measures.

\begin{tabular}{lccc}
\hline & REAT & CS & Cortisol \\
\hline FS & 0.02 & $0.51^{*}$ & 0.11 \\
REAT & & 0.07 & -0.17 \\
CS & & & 0.12 \\
\hline
\end{tabular}

FS: flight speed; REAT: reactivity; CS: composite score. $* \mathrm{P}<0.05$.

\section{Discussion}

The most efficient animals (low RFI) spent 3\% and $6 \%$ more time feeding per $\mathrm{kg}$ of DM consumed than animals with medium efficiency (medium RFI) and low efficiency (high RFI), respectively. Consequently, the FE (g DM hour ${ }^{-1}$ ) of the most efficient animals was 5\% lower than that of medium-efficiency animals and $8 \%$ lower than that of the least efficient animals. Confirming the trend of slower feeding in more efficient animals, their rumination rate $\left(\mathrm{RT}\right.$, min $\left.\mathrm{kg} \mathrm{DM}^{-1}\right)$ was $7 \%$ higher than that of medium- and low-efficiency animals.

Differences in ingestive behavior between more and less efficient animals have been reported in previous studies. In contrast to the present study, most of the data refer to European cattle breeds evaluated in automatic feeders. Richardson and Herd (2004) reported that differences in feeding patterns and activity level contributed $2 \%$ and $10 \%$, respectively, to the variation in RFI of steers born to low- and high-RFI sires. The authors observed that the least efficient steers (high RFI) spent more time standing and had a longer feeding duration than low-RFI steers. Kelly et al. (2010) and Montanholi et al. (2010) also demonstrated a shorter feeding duration and slower feeding rate for more efficient animals, suggesting that these animals (low RFI) spend less time and energy in these activities. These authors found that, respectively, $22 \%$ and $18 \%$ of the variation in RFI was explained by feeding events. Nkrumah et al. (2007) and Guimarães et al. (2017) also observed a positive correlation between feeding duration and RFI. In Bos indicus, Gomes et al. (2013) also observed less feeding time, and less time standing and more time lying, for more efficient animals. Taken together, these results confirm the hypothesis of Adam et al. (1984) who, in an assay designed to measure the energy expenditure of five steers aged 18 to 20 months, concluded that feed intake (FE, g DM day ${ }^{-1}$, in the present study) and feeding duration are the factors determining the energetic cost of feeding cattle. In other words, there is evidence that more efficient animals save energy by reducing feed intake and feeding duration.

Studying red and white blood cell parameters in steers genetically divergent for RFI, Richardson et al. (2002) hypothesized that less efficient animals (high RFI) are more susceptible to stress than more efficient animals. In beef cattle, temperament is a measure of the behavioral response to handling and can be evaluated using FS and crush score (TURNER et al., 2011). In the present study, the most efficient animals (low RFI) differed significantly from the least efficient animals (high RFI) only in terms of FS, while no difference was observed $(\mathrm{P}>0.05)$ for the other three variables used as proxies of temperament. The CS used in the present study is comparable to the crush score proposed by Grandin (1993). REAT is a measure of reactivity proposed by Maffei et al. (2006), which is very variable and little used in other studies.

The correlation between RFI and FS was significant, low and negative (-0.24). More efficient animals were more reactive than less efficient animals when FS was considered. Taken together, the results of the present study and of previous studies regarding the relationship between temperament and feed efficiency are consistent. 
Exit speed and crush score are negatively correlated with DMI and ADG (CAFE et al., 2011; LLONCH et al., 2016; NKRUMAH et al., 2007), demonstrating that calmer animals consume more feed and exhibit greater growth rates than more reactive animals. Considering that the variation in RFI between animals is the result of differences in digestion, heat increment, body composition, activity, and energy expenditure of metabolic processes (HERD; ARTHUR, 2009), the hypothesis that more efficient animals are less reactive has not been confirmed in previous studies on Bos taurus (NKRUMAH et al., 2007; ROLFE et al., 2011) or in the present study.

Exit speed and crush score have been found to be weakly correlated with RFI (CAFE et al., 2011; LLONCH et al., 2016; ROLFE et al., 2011), and animals with contrasting crush scores did not differ in terms of feed efficiency traits such as RFI and feed conversion ratio (LLONCH et al., 2016). Cafe et al. (2011) observed that Bos indicus animals are more reactive than Bos taurus and that the associations of FS and crush score with ADG were stronger in the former. This fact may result in differences in the relationship between temperament and feed efficiency in the two subspecies, but the authors found no evidence of an association between temperament and feed efficiency in Bos indicus. However, Nkrumah et al. (2007), studying 464 crossbred animals of different ages, reported a trend towards a difference in FS between animals classified for RFI. The most efficient animals had a higher FS $\left(2.66 \mathrm{~m} \mathrm{~s}^{-1}\right)$ than medium-efficiency $(2.50$ $\left.\mathrm{m} \mathrm{s}^{-1}\right)$ and low-efficiency animals $\left(2.43 \mathrm{~m} \mathrm{~s}^{-1}\right)$, as observed in the present study.

Serum cortisol was measured to evaluate the physiological response to stress. This hormone has been the most widely used parameter to evaluate animal stress (KELLY et al., 2010). In the present study, no difference $(\mathrm{P}>0.05)$ in serum cortisol concentration was observed between high-, mediumand low-RFI animals. The results of serum cortisol and fecal cortisol metabolite concentrations obtained for more and less efficient Bos taurus animals are contradictory (MONTANHOLI et al., 2010). Richardson and Herd (2004) reported that serum cortisol concentration of high-RFI animals can be more than twice as high as the concentration found in more efficient animals (low RFI). In Bos indicus, Gomes et al. (2013) also observed higher plasma cortisol levels in high-RFI animals. Montanholi et al. (2010) measured the levels of serum cortisol and fecal cortisol metabolites in animals classified as low, medium and high RFI. The authors reported that serum cortisol did not differ between animals, as also observed in the present study. However, the concentration of fecal cortisol metabolites was higher in low-RFI animals (more efficient), followed by medium-RFI and high-RFI animals. Serum cortisol indicates stress at the time of animal confinement, while fecal cortisol represents basal cortisol, a situation prior to confinement when stress is minimal since the animals are in their normal environment (MONTANHOLI et al., 2010). Llonch et al. (2016) also reported higher serum cortisol levels in more efficient animals.

\section{Conclusions}

In conclusion, feed efficiency is associated with ingestive behavior and with temperament in Nellore cattle. More efficient animals spend more time feeding and ruminating per $\mathrm{kg}$ DM than less efficient animals, i.e., animals with high feed efficiency consume and ruminate lower amounts of feed over the same period of time than medium- and low-efficiency animals. In addition, more efficient animals exhibit greater FS and may be considered more reactive than less efficient animals.

\section{Acknowledgements}

The authors thank São Paulo Research Foundation (Grant number 2010/52201-1) and National Council of Technological and Scientific Development of Brazil (Grant number 562783/20105) for the financial support. 


\section{References}

ADAM, I.; YOUNG, B. A.; NICOL, A. M.; DEGEN, A. A. Energy cost of eating in cattle given diets of different form. Animal Production, Cambridge, v. 38, n. 1, p. 5356, 1984.

BEEF IMPROVEMENT FEDERATION - BIF. Guidelines for uniform beef improvement programs. CUNDIFF, L. V.; VAN VLECK, L. D.; HOHENBOKEN, W. D. (Ed.). Athens: Beef Improvement Federation, 2010.

BURROW, H. M.; SEIFERT, G. W.; CORBET, N. J. A new technique for measuring temperament in cattle. Australian Society of Animal Production, Rockhampton, v. 17, n. 1, p. 154-157, 1988.

CAFE, L. M.; ROBINSON, D. L.; FERGUSON, D. M.; MCINTYRE, B. L.; GEESINK, G. H.; GREENWOOD, P. L. Cattle temperament: persistence of assessments and associations with productivity, efficiency, carcass and meat quality traits. Journal of Animal Science, Champaign, v. 89, n. 5, p. 1452-1465, 2011.

FORDYCE, G.; GODDARD, M. E.; SEIFERT, G. $\mathrm{W}$. The measurement of temperament in cattle and the effect of experience and genotype. Animal Production in Australia, Rockhampton, v. 14, n. 1, p. 329-332, 1982.

GOMES, R. C.; SAINZ, R. D.; LEME, P. R. Protein metabolism, feed energy partitioning, behavior patterns and plasma cortisol in Nellore steers with high and low residual feed intake. Revista Brasileira de Zootecnia, Viçosa, MG, v. 42, n. 1, p. 44-50, 2013.

GRANDIN, T. Behavioral agitation during handling of cattle is persistent over time. Applied Animal Behaviour Science, Edinburgh, v. 36, n. 1, p. 1-9, 1993.

GRION, A. L.; MERCADANTE, M. E. Z.; CYRILLO, J. N. S. G.; BONILHA, S. F. M.; MAGNANI, E.; BRANCO, R. H. Selection for feed efficiency traits and correlated genetic responses in feed intake and weight gain of Nellore cattle. Journal of Animal Science, Champaign, v. 92, p. 955-965, 2014.

GUIMARÃES, A. L.; MERCADANTE, M. E. Z.; CANESIN, R. C.; BRANCO, R. H.; LIMA, M. L. P.; CYRILLO, J. N. S. G. Phenotypic association between feed efficiency and feeding behavior, growth and carcass traits in Senepol cattle. Revista Brasileira de Zootecnia, Viçosa, MG, v. 46, n. 1, p. 47-55, 2017.

HERD, R. M.; ARTHUR, P. F. Physiological basis for residual feed intake. Journal of Animal Science,
Champaign, v. 87, n. 14, E64-71, 2009. Supplement.

KELLY, A. K.; MCGEE, M.; CREWS JUNIOR, D. H.; FAHEY, A. G.; WYLIE, A. R.; KENNY, D. A. Effect of divergence in residual feed intake on feeding behavior, blood metabolic variables, and body composition traits in growing heifers. Journal of Animal Science, Champaign, v. 88, n. 1, p. 109-123, 2010.

KOCH, R. M.; SWINGER, L. A.; CHAMBERS, D.; GREGORY, K. E. Efficiency of feed use in beef cattle. Journal of Animal Science, Champaign, v. 22, n. 2, p. 486-494, 1963.

LLONCH, P.; SOMARRIBA, M.; DUTHIE, C.-A.; HASKELL, M. J.; ROOKE, J. A.; TROY, S.; ROEHE, R.; TURNER, S. P. Association of temperament and acute stress responsiveness with productivity, feed efficiency, and methane emissions in beef cattle: An observational study. Frontiers in Veterinary Science, Davis, v. 3, Article 43, 2016.

MAFFEI, W. E.; BERGMANN, J. A. G.; PINOTTI, M.; OLIVEIRA, M. E. C.; SILVA, C. Q. Reatividade em ambiente de contenção móvel: uma nova metodologia para avaliar o temperamento bovino. Arquivo Brasileiro de Medicina Veterinária e Zootecnia, Belo Horizonte, v. 58, n. 6, p. 1123-1131, 2006.

MONTANHOLI, Y. R.; SWASON, K. C.; PALME, R.; SCHENKEL, F. S.; MCBRIDE, B. W.; LU, D.; MILLER, S. P. Assessing feed efficiency in beef steers thought feeding behavior, infrared thermography and glucocorticoids. Animal, Cambridge, v. 4, n. 5, p. 692$701,2010$.

NASCIMENTO, C. F.; BRANCO, R. H.; BONILHA, S. F. M.; CYRILlO, J. N. S. G.; NEGRÃO, J. A.; MERCADANTE, M. E. Z. Residual feed intake and blood variables in young Nellore cattle. Journal of Animal Science, Champaign, v. 93, n. 3, p. 1318-1326, 2015.

NKRUMAH, J. D.; CREWS JUNIOR, D. H.; BASARAB, J. A.; PRICE, M. A.; OKINE, E. K.; WANG, Z.; LI, C.; MOORE, S. S. Genetic and phenotypic relationships of feeding behavior and temperament with performance, feed efficiency, ultrasound, and carcass merit of beef cattle. Journal of Animal Science, Champaign, v. 85, n. 10, p. 2382-2390, 2007.

PACHECO, P. S.; RESTLE, J.; VAZ, F. B.; FREITAS, K. A.; PADUA, J. T.; NEWMANN, M.; ARBOITTE, M. $Z$. Avaliação econômica da terminação em confinamento de novilhos jovens e superjovens de diferentes grupos genéticos. Revista Brasileira de Zootecnia, Viçosa, MG, v. 35, n. 1, p. 309-320, 2006. 
PIOVEZAN, U.; CYRILLO, J. N. S. G.; PARANHOS DA COSTA, M. J. R. Breed and selection line differences in the temperament of beef cattle. Acta Scientiarum. Animal Sciences, Maringá, v. 35, n. 2, p. 207-212, 2013.

RICHARDSON, E. C.; HERD, R. M. Biological basis for variation in residual feed intake in beef cattle. 2 . Synthesis of results following divergent selection. Australian Journal of Experimental Agriculture, Collingwood, v. 44, n. 5, p. 431-440, 2004.

RICHARDSON, E. C.; HERD, R. M.; COLDITZ, I. G.; ARCHER, J. A.; ARTHUR, P. F. Blood cell profiles of steer progeny from parents selected for and against residual feed intake. Australian Journal of Experimental Agriculture, Collingwood, v. 42, n. 7, p. 901-908, 2002.
ROLFE, K. M.; SNELLING, W. M.; NIELSEN, M. K.; FREETLY, H. C.; FERRELL, C. L.; JENKINS, T. G. Genetic and phenotypic parameter estimates for feed intake and other traits in growing beef cattle, and opportunities for selection. Journal of Animal Science, Champaign, v. 89, n. 11, p. 3452-3459, 2011.

TURNER, S. P.; NAVAJAS, E. A.; HYSLOP, J. J.; ROSS, D. W.; RICHARDSON, R. I.; PRIETO, N.; BELL, M.; JACK, M. C.; ROEHE, R. Associations between response to handling and growth and meat quality in frequently handled beef cattle. Journal of Animal Science, Champaign, v. 89, n. 12, p. 4239-4248, 2011. 
